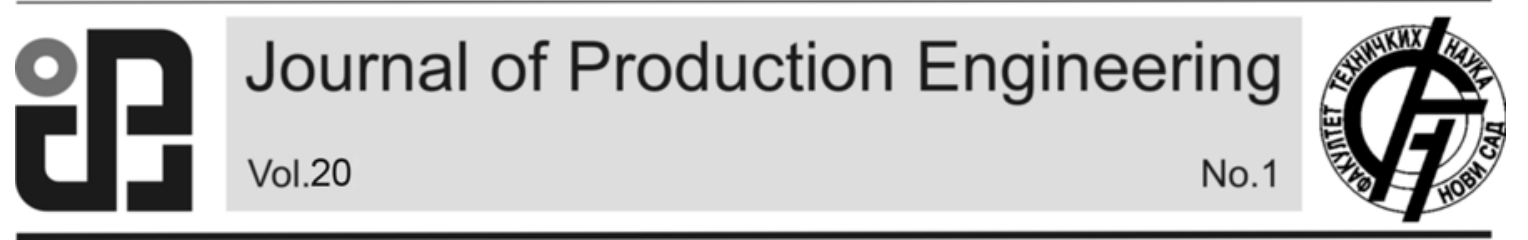

JPE (2017) Vol.20 (1)

Stanojković, J., Radovanović, M.

Preliminary Note

\title{
SELECTION OF SOLID CARBIDE END MILL FOR MACHINING ALUMINUM 6082- T6 USING CRITIC AND TOPSIS METHODS
}

Received: 30 March 2017 / Accepted: 20 April 2017

Abstract: The selection of the best end mill is a complex task because there are many alternatives and criteria to be taken into consideration when making decisions. In this paper, the selection of solid carbide end mill for machining Al 6082-T6 is presented using TOPSIS multi-criteria decision making method, where the objective weights are determined by CRITIC method. Based on the four criteria (number of end mill teeth, cutting speed, feed per tooth and the price) a selection of the most appropriate alternative of the six, i.e. from different manufacturers of cutting tools (Seco, YCT and Iscar).

Key words: multi-criteria decision, TOPSIS, CRITIC.

Izbor glodala od tvrdog metala za obradu aluminijuma 6082-T6 primenom CRITIC i TOPSIS metode. Izbor optimalnog reznog alata predstavlja problem usled postojanja velikog broja alternativa $i$ kriterijuma koje treba uzeti $u$ obzir prilikom donošenja odluke. U radu je predstavljen izbor vretenastog glodala za obradu legure aluminijuma 6082-T6 primenom TOPSIS metode višekriterijumskog odlučivanja, pri čemu je za izbor težinskih koeficijenata primenjena CRITIC metoda. Na osnovu četiri kriterijuma (broj zuba glodala, brzina rezanja, korak $i$ cena) izvršen je izbor najboje altenative od šest, tj. od šest vretenastih glodala različitih proizvođača reznih alata (Seco, Young cutting tools i Iscar).

Ključne reči: višekriterijumsko odlučivanje, TOPSIS, CRITIC.

\section{INTRODUCTION}

Multiple-criteria decision making is one of the most used methods of decision making theory. Multi-criteria decision making method is a set of mathematical methods and tools for solving real problems in different areas where there are many alternatives and criteria, i.e. objectives.

The procedure of decision making consists of the following steps: identifying the problem, gathering relevant information, identifying the alternatives and criteria, selecting among the alternatives. The process is very simple when it comes to making a decision, taking into account one criterion. In this case, the selection of an alternative is made based on the evaluation of alternative priorities. In the case where there are more criteria, it is necessary to define the objective weights for each criterion, and the importance of each criterion relative to other criteria. Objective weights are usually numbers that are subjectively selected, then for each criterion, it is determined whether it is necessary to choose an alternative so that the criterion is the maximum or minimum [1].

Today there are many numbers of multi-criteria decision making methods. In this paper, to solve the problem of selecting a solid carbide end mill for machining Al 6082-T6 the CRITIC method is used for determining the objective weights and the TOPSIS method for determining the best alternative based on defined criteria and methods.

\section{CRITIC METHOD}

The conflict between the various criteria is one of the main problems in multi-criteria decision making. Problem solving requires the use of complex procedures for the selection of a preferred variant or determining the order of the variables.

CRITIC (Criteria Importance Through Intercriteria Correlation) is a method for determining the value of objective weights. This method belongs to the class of correlation methods and is based on the analytical examination of the decision making matrix. This method involves determining the intensity of contrast and conflict [2].

Before using the CRITIC method for determining the objective weights it is necessary to define alternatives and the criteria based on which the selection of solid carbide end mill for machining alloy 6082-T6 will be made.

\begin{tabular}{|c|c|c|c|c|c|}
\hline \multicolumn{2}{|c|}{ Alternatives } & \multicolumn{4}{|c|}{ Criteria } \\
\hline \multirow{3}{*}{\multicolumn{2}{|c|}{$\begin{array}{l}\text { Solid carbide } \\
\text { end mills }\end{array}$}} & $\mathrm{C} 1$ & $\mathrm{C} 2$ & $\mathrm{C} 3$ & $\mathrm{C} 4$ \\
\hline & & $\mathrm{Z}_{\mathrm{n}}$ & $\begin{array}{c}\mathrm{V}_{\mathrm{c}} \\
\mathrm{m} / \mathrm{min}\end{array}$ & $\begin{array}{c}\mathrm{f}_{\mathrm{z}} \\
\mathrm{mm} / \text { tooth }\end{array}$ & $\begin{array}{l}\text { price } \\
\text { euro }\end{array}$ \\
\hline & & $\max$ & $\max$ & $\max$ & $\min$ \\
\hline $\mathrm{A}_{1}$ & $\begin{array}{c}\text { JS412 } \\
\text { (SECO) }\end{array}$ & 2 & 285 & 0.15 & 95 \\
\hline $\mathrm{A}_{2}$ & $\begin{array}{l}\text { E5E49 } \\
\text { (YCT) }\end{array}$ & 3 & 210 & 0.096 & 100 \\
\hline $\mathrm{A}_{3}$ & $\begin{array}{c}\text { JS413 } \\
\text { (SECO) }\end{array}$ & 3 & 275 & 0.15 & 105 \\
\hline $\mathrm{A}_{4}$ & $\begin{array}{l}\text { ECA-B-3 } \\
\text { (ISCAR) }\end{array}$ & 3 & 234 & 0.05 & 138 \\
\hline $\mathrm{A}_{5}$ & $\begin{array}{l}\text { EC-E-4L } \\
\text { (ISCAR) }\end{array}$ & 4 & 320 & 0.13 & 158 \\
\hline $\mathrm{A}_{6}$ & $\begin{array}{c}\text { JS554 } \\
\text { (SECO) }\end{array}$ & 4 & 300 & 0.09 & 128 \\
\hline
\end{tabular}

Table 1. Criteria and alternatives 
Six alternatives are presented in Table 1 (end mills of different manufacturers), while the criteria are: the number of end mill teeth, cutting speed, feed per tooth and price. The goal is to select an end mill with the maximum number of teeth, cutting speed and feed per tooth and the minimum price.

Determining the objective weights using the CRITIC method is performed by applying the six steps $[2,3]$.

Step 1: Determining the elements of normalized decision matrix using the equation (1).

$$
r_{i j}=\frac{x_{i j}-x_{j}}{x_{j}^{\max }-x_{j}^{\min }}
$$

Where: $x_{j}^{\max }=\max \left(x_{i j}, i=1, \ldots, m\right)$ and $x_{j}^{\min }=\min \left(x_{i j}, i=1, \ldots, m\right)$.

Based on the equation (1) normalized decision making matrix is presented in Table 2. Value $r_{i j}$ shows how an alternative is close to the ideal value $x_{j}^{\max }$ and how far it is from the anti-ideal values. The normalized matrix does not take into account the type of criteria (maximum or minimum).

Step 2: Based on the value $r_{i j}$ it is possible to form a vector of criteria, each vector has a standard deviation $\sigma_{j}$, using the equation (2), that represents the degree of deviation of alternatives for the given criterion, Table 2.

$$
\sigma_{j}=\sqrt{\frac{1}{n}\left(\sum_{i=1}^{m} r_{i j}-\bar{r}\right)^{2}}
$$

Where: $\mathrm{n}$ is a number of elements and $\bar{r}$ is an arithmetic mean.

\begin{tabular}{|c|c|c|c|c|}
\hline & $\mathrm{C}_{1}$ & $\mathrm{C}_{2}$ & $\mathrm{C}_{3}$ & $\mathrm{C}_{4}$ \\
\hline $\mathrm{A}_{1}$ & 0 & 0.682 & 1 & 0 \\
\hline $\mathrm{A}_{2}$ & 0.5 & 0 & 0.46 & 0.079 \\
\hline $\mathrm{A}_{3}$ & 0.5 & 0.591 & 1 & 0.159 \\
\hline $\mathrm{A}_{4}$ & 0.5 & 0.218 & 0 & 0.683 \\
\hline $\mathrm{A}_{5}$ & 1 & 1 & 0.8 & 1 \\
\hline $\mathrm{A}_{6}$ & 1 & 0.818 & 0.4 & 0.524 \\
\hline$\sigma_{\mathrm{j}}$ & 0.37638 & 0.37580 & 0.39471 & 0.39401 \\
\hline
\end{tabular}

Table 2. Normalized decision making matrix

Step 3: Determining a matrix $n \times n$ with elements $R_{i j}$, which represent linear correlation coefficients $r_{j}, r_{k}$, and $n$ represents a number of alternatives, using the equation (3). In the case of a large discrepancy between the values of attributes for criteria $j \mathrm{i} k$, it is the lower value of the coefficient $R_{i j}$, Table $3[3,4]$.

$$
R_{i j}=\frac{n \sum r_{j} r_{k}-\sum r_{j} \sum r_{k}}{\sqrt{n \sum r_{j}^{2}}-\left(\sum r_{j}\right)^{2} \cdot \sqrt{n \sum r_{k}^{2}-\left(\sum r_{k}\right)^{2}}}
$$

\begin{tabular}{|c|c|c|c|c|}
\hline & $\mathrm{C}_{1}$ & $\mathrm{C}_{2}$ & $\mathrm{C}_{3}$ & $\mathrm{C}_{4}$ \\
\hline $\mathrm{C}_{1}$ & 1 & 0.413229 & -0.27597 & 0.752851 \\
\hline $\mathrm{C}_{2}$ & 0.413229 & 1 & 0.514659 & 0.436627 \\
\hline $\mathrm{C}_{3}$ & -0.27597 & 0.811717 & 1 & -0.36844 \\
\hline $\mathrm{C}_{4}$ & 0.752851 & 0.436376 & -0.36844 & 1 \\
\hline
\end{tabular}

Table 3 . The coefficients of linear correlation
Step 4: Determining the rates of the conflict criteria using the equation (4), Table 4 [5].

\begin{tabular}{|c|c|c|c|c|}
\hline Criteria & $\mathrm{C}_{1}$ & $\mathrm{C}_{2}$ & $\mathrm{C}_{3}$ & $\mathrm{C}_{4}$ \\
\hline $\mathrm{C}_{1}$ & 0 & 0.586771 & 1.275973 & 0.247149 \\
\hline $\mathrm{C}_{2}$ & 0.586771 & 0 & 0.485341 & 0.563373 \\
\hline $\mathrm{C}_{3}$ & 1.275973 & 0.188283 & 0 & 1.368443 \\
\hline $\mathrm{C}_{4}$ & 0.247149 & 0.563624 & 1.368443 & 0 \\
\hline
\end{tabular}

Table 4. The rates of conflict criteria

Step 5: Determining the quantity of the information in relation to each criterion using the equation (5), Table 5.

$$
C_{j}=\sigma_{j} \sum_{k=1}^{n}\left(1-R_{j k}\right)
$$

\begin{tabular}{|c|c|c|c|c|}
\hline Criteria & $\mathrm{C}_{1}$ & $\mathrm{C}_{2}$ & $\mathrm{C}_{3}$ & $\mathrm{C}_{4}$ \\
\hline $\mathrm{C}_{1}$ & 0 & 0.586771 & 1.275973 & 0.247149 \\
\hline $\mathrm{C}_{2}$ & 0.586771 & 0 & 0.485341 & 0.563373 \\
\hline $\mathrm{C}_{3}$ & 1.275973 & 0.188283 & 0 & 1.368443 \\
\hline $\mathrm{C}_{4}$ & 0.247149 & 0.563624 & 1.368443 & 0 \\
\hline
\end{tabular}

Table 5 . Thequantity of information in relation to each criterion

The quantity of information in relation to each criterion for the given example is: $C_{j}=(0.794135$, $0.503079,1.235362,0.85855)$.

Step 6: Determining the objective weight coefficients by normalizing the value $C_{j}$ using the equation 6 , Table $6[2,3]$.

$$
w_{j}=\frac{C_{j}}{\sum_{j=1}^{n} C_{j}}
$$

\begin{tabular}{|c|c|c|c|c|}
\hline $\mathrm{C}_{\mathrm{i}}$ & 0.794135 & 0.503079 & 1.235362 & 0.85855 \\
\hline $\mathrm{w}_{\mathrm{j}}$ & 0.23418 & 0.148352 & 0.364293 & 0.253176 \\
\hline
\end{tabular}

Table 6. Objective weight coefficients

The objective weights of the criteria for selection of solid carbide end mills are: $\mathrm{w}_{\mathrm{j}}=(0.23418,0.148352$, $0.364293,0.253176)$.

\section{TOPSIS METHOD}

TOPSIS (Technique for Order Preference by Similarity to Ideal Solution) is a method based on the concepts that the chosen alternative should have the shortest distance from the ideal (positive) solution and the farthest distance from the anti-ideal (negative) solution [6].TOPSIS approach was developed by Hwang (1981). TOPSIS method is shown in Fig. 1, which represents the spatial distribution of alternative defined for two maximum criteria $\left(\mathrm{C}_{1}, \mathrm{C}_{2}\right)$. In the figure it can be observed that the alternative $\mathrm{A} 1$ although closer to the ideal solution $(\mathrm{A}+)$ in comparison with alternative $A_{2}$, is at the same time closer to the antiideal solution (A-) in comparison with alternative $A_{2}$. 


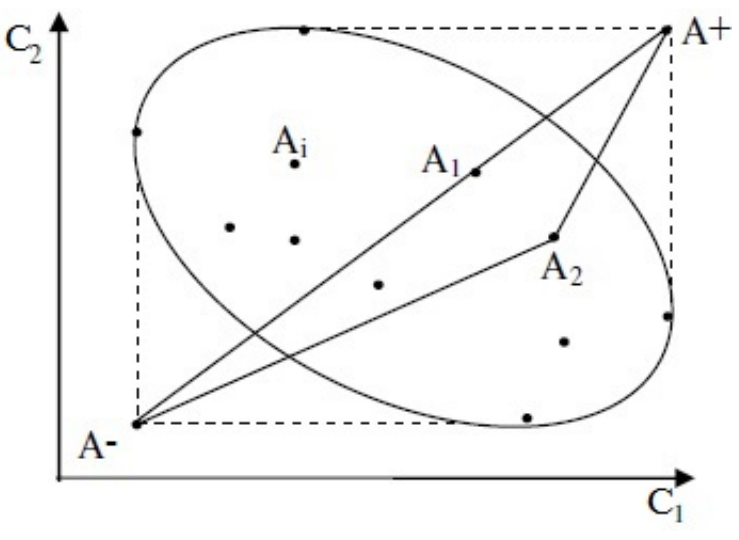

Fig. 1. TOPSIS method

TOPSIS method is performed by applying the nine steps [2, 3, 4]

Step 1: Determining the objective, alternatives and criteria.

The objective is to evaluate the six alternatives (solid carbide end mills from different manufacturers of cutting tools for machining aluminum alloy 6082-T4) based on the four criteria (number of teeth, cutting speed, feed per tooth and price) from which one criterion is minimized, in this case the price of the slolic carbide end mill.

Step 2: Based on the given values the decision matrix $X(7)$ is defined [6]:

$$
X=\left[x_{i j}\right]=\left|\begin{array}{cccc}
x_{11} & x_{12} & \cdots & x_{1 n} \\
x_{21} & x_{22} & \cdots & x_{2 n} \\
\vdots & \vdots & \vdots & \vdots \\
x_{m 1} & x_{m 2} & \cdots & x_{m n}
\end{array}\right|
$$

Based on the values of the Table 1, decision matrix (8) for selection of solid carbide end mills is given:

$$
X=\left[x_{i j}\right]=\left|\begin{array}{cccc}
2 & 285 & 0.15 & 95 \\
3 & 210 & 0.096 & 100 \\
3 & 275 & 0.15 & 105 \\
3 & 234 & 0.05 & 138 \\
4 & 320 & 0.13 & 158 \\
4 & 300 & 0.09 & 128
\end{array}\right|
$$

Step 3: Normalization of the decision matrix, Table 7 , is calculated by equation $(9)[7,8]$ :

$$
r_{i j}=\frac{x_{i j}}{\sqrt{\sum_{n=1}^{m} x_{i j}^{2}}}
$$

\begin{tabular}{|c|c|c|c|c|}
\hline $\mathrm{A}_{1}$ & 0.251976 & 0.42575 & 0.524732 & 0.315892 \\
\hline $\mathrm{A}_{2}$ & 0.377964 & 0.31371 & 0.335829 & 0.332518 \\
\hline $\mathrm{A}_{3}$ & 0.377964 & 0.410811 & 0.524732 & 0.349144 \\
\hline $\mathrm{A}_{4}$ & 0.377964 & 0.349563 & 0.174911 & 0.458875 \\
\hline $\mathrm{A}_{5}$ & 0.503953 & 0.478035 & 0.454768 & 0.525378 \\
\hline $\mathrm{A}_{6}$ & 0.503953 & 0.448158 & 0.314839 & 0.425623 \\
\hline
\end{tabular}

Table 7. Normalized the decision matrix
Step 4: Determining the values of the objective weight coefficients with the following equation (10) [2, 3]:

$$
\sum_{j}^{n} w_{j}=1
$$

Critic method is used for determining the objective weight coefficients $\mathrm{w}_{\mathrm{j}}=(0.23418,0.148352,0.364293$, $0.253176)$.

Step 5: Determining the weighted decision making matrix represents the multiplication of elements of a column of the normalized matrix with appropriate objective weight coefficients by using the equation (11) [7]:

$$
v_{i j}=r_{i j} \cdot w_{j}
$$

Weight normalized decision making matrix for the selection of solid carbide end mills is shown in Table 8:

\begin{tabular}{|c|c|c|c|c|}
\hline $\mathrm{A}_{1}$ & 0.059008 & 0.063161 & 0.191156 & 0.079976 \\
\hline $\mathrm{A}_{2}$ & 0.088512 & 0.046539 & 0.12234 & 0.084185 \\
\hline $\mathrm{A}_{3}$ & 0.088512 & 0.060945 & 0.191156 & 0.088395 \\
\hline $\mathrm{A}_{4}$ & 0.088512 & 0.051858 & 0.063719 & 0.116176 \\
\hline $\mathrm{A}_{5}$ & 0.118016 & 0.070917 & 0.165669 & 0.133013 \\
\hline $\mathrm{A}_{6}$ & 0.118016 & 0.066485 & 0.114694 & 0.107757 \\
\hline
\end{tabular}

Table 8 . Weight normalized decision making matrix

Step 6: Identifying the positive and negative ideal solution based on the equations (12) and (13) [8]:

$$
\begin{aligned}
& V^{+}=\left\{\max \left(v_{i j}\right), j \in J, \min \left(v_{i j}\right), j \in J, i=1, \ldots, m\right\}=\left\{V_{1}^{+}, V_{2}^{+}, \ldots, V_{n}^{+}\right\} \\
& V^{-}=\left\{\min \left(v_{i j}\right), j \in J, \max \left(v_{i j}\right), j \in J, i=1, \ldots, m\right\}=\left\{V_{1}^{-}, V_{2}^{-}, \ldots, V_{n}^{-}\right\}
\end{aligned}
$$

With the maximum criteria it has the highest value of the attribute, while with the minimum criteria it has the lowest value of the attribute. Positive and negative solution values of the attribute relative to each criterion are given in Table 9.

\begin{tabular}{|l|l|}
\hline$V_{C 1}{ }^{+}=0.118016$ & $V_{C 1^{-}}=0.059008$ \\
\hline$V_{C 2}{ }^{+}=0.070917$ & $V_{C 2^{-}}=0.046539$ \\
\hline$V_{C 3}{ }^{+}=0.191156$ & $V_{C 3^{-}}=0.063719$ \\
\hline$V_{C 4}{ }^{+}=0.079976$ & $V_{C 4^{-}}=0.133013$ \\
\hline
\end{tabular}

Table 9. Positive and negative solution

Step 7: Calculating the separation distance of each competitive alternative from the positive and negative solution based on the equations (14) and (15) [8,9]:

$$
\begin{aligned}
& S_{i}^{+}=\sqrt{\sum_{j=1}^{n}\left(v_{i j}-V_{j}^{+}\right)^{2}} \\
& S_{i}^{-}=\sqrt{\sum_{j=1}^{n}\left(v_{i j}-V_{j}^{-}\right)^{2}}
\end{aligned}
$$

Separation distance of each competitive alternative from the positive and negative solution for selection of solid carbide end mills are given in Table 10. 


\begin{tabular}{|c|c|}
\hline$S_{A 1}{ }^{+}=0.059515$ & $S_{A 1^{-}}=0.13903$ \\
\hline$S_{A 2^{+}}=0.078855$ & $S_{A 2^{-}}=0.081799$ \\
\hline$S_{A 3}{ }^{+}=0.032262$ & $S_{A 3^{-}}=0.138957$ \\
\hline$S_{A 4}{ }^{+}=0.137056$ & $S_{A 4^{-}}=0.034384$ \\
\hline$S_{A 5}{ }^{+}=0.058843$ & $S_{A 5^{-}}=0.120291$ \\
\hline$S_{A 6}{ }^{+}=0.081474$ & $S_{A 6^{-}}=0.084357$ \\
\hline
\end{tabular}

Table 10. Distance of each competitive alternative from the positive and negative solution

Step 8: Measuring the relative closeness of each location of the ideal solution $P_{i}$, Table 11. For each competitive alternative the relative closeness of the potential location with respect to the ideal solution is calculated by equation (16) [8]:

$$
P_{i}=\frac{S_{i}^{-}}{S_{i}^{+}+S_{i}^{-}}
$$

\begin{tabular}{|c|c|}
\hline Alternative & $\mathrm{P}_{\mathrm{i}}$ \\
\hline $\mathrm{A}_{1}$ & 0.700243 \\
\hline $\mathrm{A}_{2}$ & 0.509161 \\
\hline $\mathrm{A}_{3}$ & 0.811577 \\
\hline $\mathrm{A}_{4}$ & 0.20056 \\
\hline $\mathrm{A}_{5}$ & 0.671514 \\
\hline $\mathrm{A}_{6}$ & 0.508693 \\
\hline
\end{tabular}

Table 11. Relative closeness of each location of the ideal solution

Step 9: According to the value of $P_{i}$ the order of the alternatives is A3-A1-A5-A2-A6-A4, which means that in the first place it is an alternative A3, i.e. JS413 solid carbide end mill by Seco.

\section{CONCLUSION}

There is a large number of methods for implementing multi-criteria decision making analysis. For the selection of solid carbide end mills for machining aluminum alloy 6082-T6 TOPSIS method was used for ranking alternatives based on the criteria. To determine the objective weight coefficients CRITIC method was used. Based on the four criteria (number of teeth cutters, cutting speed, feed per tooth and price) the first choice is solid carbide end mill JS413 (Seco), thenJS412 (Seco), EC-E-4L (Iscar), E5E49 (Young Cutting Ttools), JS554 (Seco) and finally ECA-B-3 (Iscar).

\section{REFERENCES}

[1] Hwang, C. L. \& Yoon, K..: Multiple-criteria decision making: Methods and Applications, A state of art survey. New York. Springer-Verlag, 1981.

[2] Madić, M., Nedić, B., Radovanović, M.: Business and Engineering Decision Making by by using Multi-Criteria Decision Making Methods, University of Kragujevac, 2015.

[3] Madić, M, Radovanović, M.: Ranking of some most commonly used nontraditional machining process using ROV and CRITIC methods, U.P.B. Sci. Bull., Series D, Vol. 77, No. 2, p.p. 193-204,
2015.

[4] Milić, M., Župac, G.: An objective approach to determining the weight criteria, Original Bulletin, Vol. 29, No. 2, p.p. 39-56. 2012.

[5] Diakoulaki, D., Mavrotas, G. Papayannakis, L.: Determining objective weights in multiple criteria problems: The critic method Computers and Operations Research, Vol. 22, No. 7, p.p. 763-770, 1995.

[6] Srikrishna, S., Sreenivasulu, A., Vani, S.: A New Car Selection in the Market using TOPSIS Technique, International Journal of Engineering Research and General Science, Vol. 2, No. 4, p.p. 177-181, 2014.

[7] Naga, A. Phaneendra, A, Diwakar Reddy, V., Srikrishn, S.: TOPSIS Based Approach for Selection of Third Party Reverse Logistics Service Provider: A Case Study of Mobile Phone Industry, Imperial Journal of Interdisciplinary Research (IJIR), Vol. 2, No. 4, p.p. 177-181, 2016.

[8] Balli, S. Korukoglu, S.: Operating System Selection Using Fuzzy AHP and TOPSIS Methods, Mathematical and Computational Applications, Vol. 14, No. 2, p.p. 119-130, 2009.

[9] Malaki, A., Owens, G., Bruce, D.: Combining AHP and TOPSIS Approaches to Support Site Selection for Lead Pollution Study, $2^{\text {nd }}$ International Conference on Environmental and Agriculture Engineering, Vol. 37, p. p. 1-7, 2012.

\section{ACKNOWLEDGEMENT}

The paper is a part of the research done within the project TR35034. The authors would like to thank to the Ministry of Education and Science, Republic of Serbia

Authors: Jelena Stanojković, PhD student, Prof. Dr. Miroslav Radovanović, University of Niš, Faculty of Mechanical Engineering in Niš, Aleksandra Medvedeva 14, 18000 Niš, Serbia, Phone: +381 18 500-687, Fax: +381 18 588-244;

E-mail: jstanojkovic@masfak.ni.ac.rs mirado@masfak.ni.ac.rs 